International Research Journal of Management, IT \& Social Sciences
Available online at https://sloap.org/journals/index.php/irjmis/
Vol. 8 No. 6, November 2021, pages: 661-668
ISSN: 2395-7492
https://doi.org/10.21744/irjmis.v8n6.1959

\title{
Work Culture of the Government of Teluk Ambon District in Providing Administrative Services to the Community in the Era of COVID-19
}

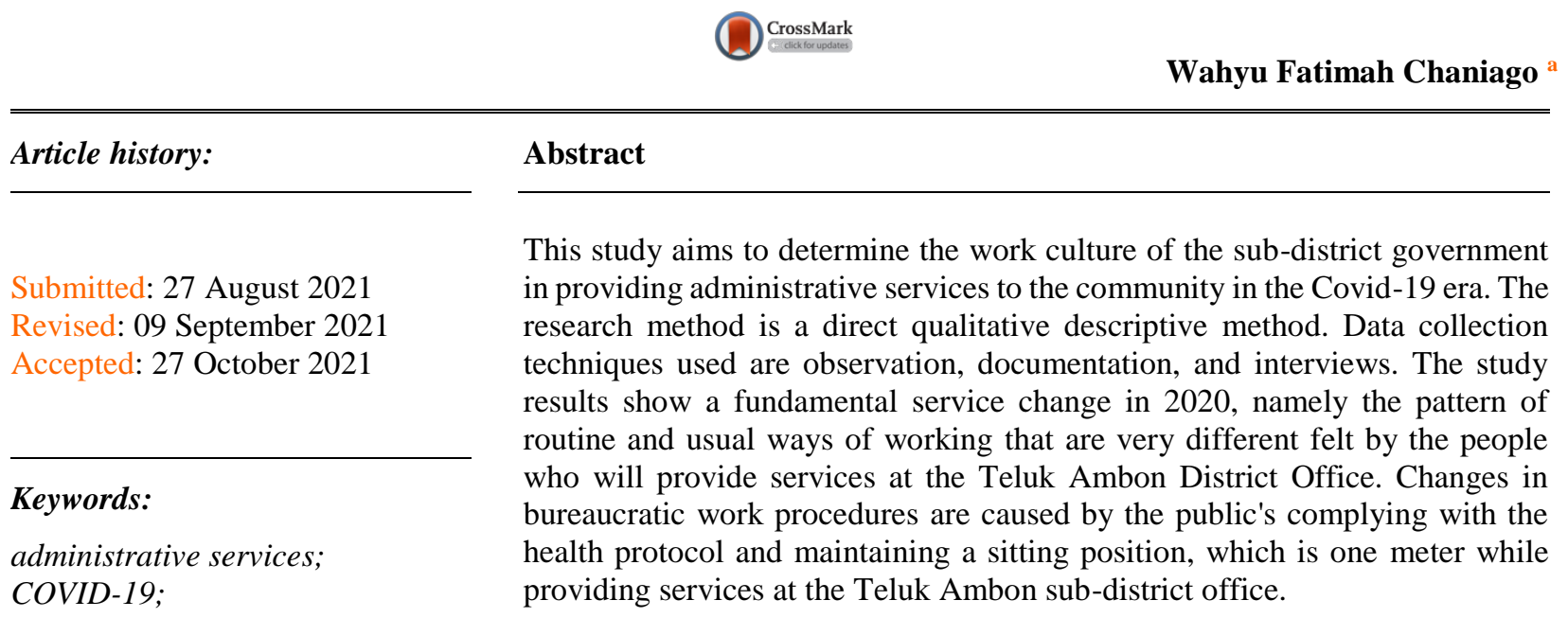
government; pattern change; work culture;

International research journal of management, IT and social sciences (C) 2021. This is an open access article under the CC BY-NC-ND license (https://creativecommons.org/licenses/by-nc-nd/4.0/).

\section{Corresponding author:}

Wahyu Fatimah Chaniago,

Universitas Pattimura, Ambon, Indonesia

Email address: wahyufatimahmpa@gmail.com

a Universitas Pattimura, Ambon, Indonesia 


\section{Introduction}

The COVID-19 pandemic has taught us a lot in terms of bureaucratic governance. In any case, the bureaucracy must remain at the forefront of providing public services. The COVID-19 era has forced the bureaucracy to optimize technology, information, and communication in all matters in the government sector. Due to the limited space for movement due to following health protocols, people are still given their rights as citizens to be served through electronic services. The transformation of the manual service model marked by face-to-face to electronic services continues to experience a significant spike during the COVID-19 period. Various technology applications are optimized for their functions to provide services to the community. In public services and maximizing the use of technology is also carried out in-office meetings, filling in employee performance and other activities. Conditions like this are in front of us and require a change towards a new normal life, including how the bureaucracy provides public services (Brown \& Brignall 2007; Casu \& Thanassoulis, 2006).

It was not optimal from the results of initial observations at the Teluk Ambon District office regarding administrative services during the COVID-19 pandemic. There are still many people who are still confused about the service procedure, the correspondence mechanism. Meanwhile, there are no posters or billboards at the sub-district office to provide information to people who want to do the management. These factors are why the working mechanism and control of the administration are still unclear, which is good, easy, and committed to quality. To avoid the spread of COVID-19 in the community, the Ambon city government provides administrative services to the community through the whatshapp listed in front of the office. With the implementation of PSBB in Ambon City, the Ambon Bay sub-district office decided that administrative services would be carried out by a work from home system. From the background described, there is a new work procedure change in the government bureaucracy in Ambon City, namely the work system carried out through electronic-based services either through whatshapp or others. The shift in the way of working certainly impacts and changes in services that the community feels as subjects who receive direct services and require appropriate and transparent services. The shift in bureaucratic work procedures for the Teluk Ambon subdistrict office in the COVID-19 era has become very interesting and the latest to understand the work culture and public services provided by the Teluk Ambon District Office in the COVID-19 Era (Tetro, 2020; Kim \& Su, 2020).

When viewed from Lewin's opinion, the change in the new bureaucracy to the new normal is an external force that demands changes in the bureaucracy. With the COVID-19 pandemic, it is hoped that the bureaucracy will quickly adapt and respond. The bureaucracy that was sluggish in responding to the COVID-19 handling situation also occurred for the first time when the Indonesian Government announced Covid-19 as a national epidemic which was very far from when the virus was first revealed in Wuhan, China (Amrynudin \& Katharina, 2020). There are still disparities in life expectancy in 7 districts in Maluku Province (Matdoan et al., 2021). However, this provision is considered contrary to the Minister of Health Regulation No. 9 of 2020 concerning PSBB Guidelines in the Context of Accelerating the Handling of COVID-19, which prohibits motorcycle taxis from operating to transport people, only transporting goods.

The optimal management of human resources for the apparatus will balance the needs of the instrument and the demands of the organization on the instrument so that an increase in the performance and existence of the organization is realized. According to Notoatmodjo (1992), the primary purpose of personnel management is to increase the contribution of human resources to the organization to achieve organizational productivity. Lewin's change model defines three change processes, namely: unfreeze, change, and refreeze. The stages are as follows: (1) in the early stages of change (unfreezing the status quo). (2). Stages of the Transition Process (Movement to the new state). (3).In the Refreezing stage. At this stage, it is more about efforts to strengthen the changes that have been made so that they can run well, dynamically, and stable. Organizations standardize these changes as the new norm (Lewin, 1951).

The Indonesian bureaucracy is still lagging behind other countries in formulating policies quickly and accurately to respond to the world situation, which is constantly changing and moving dynamically, especially in information, communication, and technology (ICT) (Purwanto, 2019). Policymakers in the regions need to consider the concept of a new public service model as a new paradigm in the implementation of public services in local government (Miftah Thoha, 2010). Community groups oversee implementing social assistance programs carried out by the village government (Tuanaya et al., 2020). The primary mission of the government is essential to make improvements (development), not to make money (Osborne \& Gaebler, 1996). This is explained by Hugest (1994), that the government has an essential role in determining the basic standard of living. Many people depend on government services such as the quality of education, health, public transportation, environment, law, urban planning, etc. Attitudes consist of essential components, namely emotions, information, and behavior (Luthans, 2006). The perspective of The New Public Service has many facets and demands recognition of the complex role played by the government (bureaucrats) in contemporary governance (Herizal et al., 2020). 
Meanwhile, Gibson in Sedarmayanti states that "attitude is a positive or negative feeling or mental state that is always prepared, learned and regulated through experience that has a special influence on a person's response" (Sedarmayanti, 1996). The practice of giving money makes things smooth in the bureaucracy, which still often happens and causes people to be better and happier to deal with the private sector compared to government agencies (Ashari, 2019). The COVID-19 pandemic has changed the paradigm of the civil state apparatus working system to be more effective and efficient, more result-oriented than procedural. Civil state apparatus continues to provide excellent public services to the community during the COVID-19 pandemic. However, the health and safety of civil state apparatus is a top priority during the COVID-19 pandemic. Therefore, even though the new normal policy has been implemented, civil state apparatus still adheres to and carries out health protocols at work. According to Ibrahim et al. (2021), regulation is a form of delegation of authority and adjusting conditions to aspects of the bureaucratic structure.

The COVID-19 pandemic has changed many things in work life, including bureaucracy. Facing the new normal situation, the government made several adjustments to the new workspace, namely designing bureaucratic changes using various technological developments. According to Gomes et al. (2015), there are five main components of changing the unique workspace of the bureaucracy, namely: (1). Flexible and networked workspace. (2). Infrastructure setup and learning super application (super app) that enables virtual and digital offices. (3). Increasing the capability of Civil state apparatus in interacting with various advances in information and communication technology, including big data and artificial intelligence, is very much needed. (4). In the new normal era after Covid 19, business processes and bureaucratic workflows must be arranged immediately. (5). The new normal era of bureaucracy requires qualified and competent Civil state apparatus employees to manage the new workspace (Parent et al., 2005; Yildiz, 2007).

This framework uses several theoretical approaches to analyze changes in work procedures in the government bureaucracy. The path to the concept of new work culture amid COVID-19 requires that the services provided change entirely. So that the service is not normal, it needs a very competitive speed of service and innovation to adapt to the use of technology. Employees who master information technology can provide excellent and fast service and provide education to the public as service recipients that changes in work culture are caused by the COVID-19 situation, which has changed the service model (Verburg et al., 1999; Nagendra et al., 2004).

\section{Materials and Methods}

The type of descriptive research describes certain social phenomena related to the problem and is to be researched in detail (Nazir, 1988; Phillippi \& Lauderdale, 2018; Porter et al., 2016; Gumilang, 2016; Grbich, 2012). The purpose of descriptive research (Descriptive Research) is to make a systematic, factual, and accurate hostage regarding the facts and characteristics of a particular population or area (Suryabrata, 2011).

Research subjects are people who understand the problems being studied. According to Moleng, research subjects can be used to provide information about the situation and condition of research (Basrowi, 2008). While the object of research is something to be researched (Tatang, 1995). The technique of determining the research subject here uses a purposive technique, which is choosing a subject based on specific characteristics that have been previously known to achieve research objectives (Hadi, 1967). The purpose of the purposive technique is to choose the subject to be interviewed deliberately. The data analysis unit in this study is the Teluk Ambo District Government, Office Employees, and the community.

Table 1

Research informants

\begin{tabular}{lc}
\hline \multicolumn{1}{c}{ Village government } & Number of Respondents \\
\hline District Head of Teluk Ambon & 1 person \\
District Secretary & 1 person \\
District office employee & 3 people \\
People & 3 people \\
Amount & 8 people \\
\hline
\end{tabular}

Source: Research Informants, 2020

Chaniago, W. F. (2021). Work culture of the government of Teluk Ambon district in providing administrative services to the community in the era of COVID-19. International Research Journal of Management, IT and Social Sciences, 8(6), 661-668. https://doi.org/10.21744/irjmis.v8n6.1959 
Data collection techniques in this study are using interviews and documentation. Because qualitative research can understand its meaning well, if a direct relationship is carried out with the subject through in-depth interviews and documentation is needed to complete the data. According to Nazir (1988), data collection is the procurement of the data required to strengthen the arguments and assumptions in proving the truth of the research. Nazir (1988), that the data collected must be valid enough to be used. The validity of the data can be improved if the measuring instrument and the quality of the data collection itself are right (Ali et al., 2015; Holmes \& Marra, 2002).

\section{Results and Discussions}

\section{Changes in administrative culture during the COVID-19 period at the teluk Ambon district office}

Factors-Factors that influence bureaucratic behavior in administrative services, according to Dwiyanto (2013), are determined by organizational leadership, apparatus competence, awarding, and availability of work facilities. These factors support and inhibit the success of bureaucratic behavior from realizing service optimization as one of the organizational goals. The following describes the factors that influence bureaucratic behavior consisting of:

\section{Leadership}

According to Hasibuan \& Hasibuan (2016), organizational leadership is an essential factor in determining bureaucratic behavior. Strong leadership gives excellent support to the conduct of the apparatus to provide bureaucratic achievements. On the other hand, weak leadership is a weakness factor that affects bureaucratic behavior that cannot develop and advance in realizing organizational goals. Miftah Thoha (2010), distinguishes the definition of leader from leadership. Leadership is the right of every person to be a leader, whether leading himself, his family, community groups, or organizations. At the same time, leadership is a person's right to lead because it is appointed based on the agreement of decisions based on rules. So leadership tends to be the appointment of a person based on a position recognized by binding regulations to lead to direct, move, and influence his subordinates to achieve common goals. From the results of interviews with the Ambon Bay District Head about the influence of leadership in responding to administrative services during the COVID-19 pandemic, they are as follows:

\footnotetext{
We feel that the service during the COVID-19 situation at the Teluk Ambon District office could run well, quickly and precisely because I was a leader can provide work motivation to improve services without knowing any conditions. I feel that the role of a leader in an organization is vital to provide advice and oversee the service process during the COVID-19 pandemic (Interview results on October 10, 2020, 15:11 Wit).
}

The results of the interviews above can be analyzed under the influence of leadership in encouraging and providing work motivation for employees in increasing work productivity, which is very important in managing government organizations. Leadership factors can give a performance burden to employees in improving performance in serving the community during the COVID-19 pandemic.

\section{Competence}

Mangkunegara (2011), stated that the vital philosophy of bureaucratic behavior is improving apparatus competence. Competence is a factor that determines the success or failure of a person in developing bureaucratic behavior. The competence of the apparatus is determined by the knowledge, skills, experience, and mastery of work that makes the instrument capable of developing good bureaucratic behavior, while the competence of the apparatus with low knowledge, unskilled, inexperienced, and incompetent influences a person's difficulty in developing bureaucratic behavior. Competence is an important part of the success of human resources in realizing company goals. Competence comes from the word competent, which means capable of being commensurate with the word ability. This competence is related to the potential of individual human resources in behaving and acting to achieve their goals. Based on the results of interviews with the Ambon Bay District Head, the competencies possessed by both Civil state apparatus/ Non-Civil state apparatus employees to provide good service during the COVID-19 period are as follows:

The competence possessed by employees is essential, both in terms of work experience and level of education. We strive to improve the competencies possessed by employees through training and training in stages. Tiered training can encourage the improvement of the quality of good public services at the Teluk Ambon sub-district office. In the COVID-19 condition, we feel 
a change, but office employees can adjust to conditions and services through whatsapp communication and maintain distance while serving at the Teluk Ambon District office. (Interview Results, October 11, 2020, 10:00 WIT).

The interview results above show that the Teluk Ambon District Office employees are always given quality improvement through training and training and leadership training to improve the quality of public services at the Teluk Ambon District office. During the COVID-19 pandemic, services can be carried out by maintaining health protocols and maintaining distance while services are carried out at the Teluk Ambon District Office.

Award

Suparman (2005), states that awards are one of the factors that influence bureaucratic behavior. Reward and recognition are essential aspects in the implementation of bureaucratic behavior. Everyone likes to get praise, recognition, achievement, pride in work because every job that receives an award improves one's bureaucratic behavior. On the other hand, organizations that rarely give awards affect the morale and mentality of the apparatus to behave positively in carrying out their work activities. Appreciation is a basic human trait that is owned by every individual organization. Therefore, this trait always drives humans to make changes in themselves that arise from within or from outside humans, which gives birth to motivation. Every human being has a motivation for what they do because they expect recognition and praise, promotions, awards, and mutations. The award is the respect given by other people as a form of appreciation for the activities they make, which are determined by educational background, work experience, work discipline, and rank/class (Mangkunegara, 2011).

Ndraha (1999), awards as a form of motivation that is highly expected by individual organizations in carrying out their work activities. None of the organization's individuals who carry out work activities do not require recognition/praise for the work achieved, job promotions, awarding services, and work mutations for what has been done in achieving organizational goals. The award is determined by educational background, work experience, work discipline, and rank/class owned by human resources so that they deserve to be promoted. Bureaucracy does not always continue to get bad reviews and perform sluggishly. There are positive policies produced by the bureaucracy that needs to be appreciated in handling COVID-19 in Indonesia. The Ministry of State Civil Apparatus issued several regulations to provide services during the COVID-19 pandemic. This guide is a form of government response in service delivery to prepare for service optimization when undergoing a new habit period.

Table 1

Service readiness matrix for teluk Ambon district

\begin{tabular}{lll}
\hline No & \multicolumn{1}{c}{ Waiter Readiness During COVID-19 } & \multicolumn{1}{c}{ Description } \\
\hline 1 & Availability of Sanitation and Hygiene Facilities & Available \\
& $\checkmark \quad$ Clean Toilet & \\
& $\checkmark \quad$ Suggestion for handwashing with running water using soap or & \\
& $\quad$ hand sanitizer & \\
& $\checkmark \quad$ Disinfectant & \\
2 & Service readiness by using masks while at the Teluk Ambon District office & Must \\
3 & Has a body temperature gauge & Available \\
4 & Service seat 1-meter distance & Available \\
5 & Maximum service one day 10 services & Must \\
\hline
\end{tabular}

Source: Field Process Analysis, 2020

Service is one of the spearheads of customer satisfaction efforts and is a must that must be optimized both by individuals and organizations because the form of services provided reflects the quality of individuals or organizations that provide services. According to ivancevich, Lorenzi, Skinner, and Crosby Ratminto \& Atik, "services are invisible products (cannot be touched) that involve human efforts and use equipment. Service is associated with public administration can be defined as the quality of service bureaucrats to the community. The definition of service in detail proposed by Gronroos Sutrisno (2009), namely: Service is an activity or a series of invisible activities (cannot be touched) that occur due to interactions between consumers and employees or other things provided by the company.

Chaniago, W. F. (2021). Work culture of the government of Teluk Ambon district in providing administrative services to the community in the era of COVID-19. International Research Journal of Management, IT and Social Sciences, 8(6), 661-668. https://doi.org/10.21744/irjmis.v8n6.1959 
Service provider companies are intended to solve consumer or customer problems (Kawiana et al., 2018; Mandala et al., 2019).

\section{Conclusion}

Based on the results of the analysis and interpretation of the existing data or discussion, it can be concluded that several important things are as follows: Changes in bureaucratic work procedures during the COVID-19 pandemic, from the results of the study showed that there was a fundamental service change in 2020, namely the pattern of changes in normal and normal ways of working very differently felt by the people who would provide services at the Teluk Ambon District Office. The difference in bureaucratic work procedures was because the public during the service at the Teluk Ambon sub-district office had to comply with the health protocol and maintain a sitting position of one meter. Before entering the office, you must wash your hands provided by the Ambon Bay sub-district government.

Conflict of interest statement

The author declared that she have no competing interests.

Statement of authorship

The author have a responsibility for the conception and design of the study. The author have approved the final article.

Acknowledgments

Our gratitude goes to the Faculty of Social and Political Sciences, Universitas Pattimura, Ambon, Indonesia for providing input and support to publish in reputable international journals. 


\section{References}

Ali, N. M., Jangga, R., Ismail, M., Kamal, S. N. I. M., \& Ali, M. N. (2015). Influence of leadership styles in creating quality work culture. Procedia Economics and Finance, 31, 161-169. https://doi.org/10.1016/S22125671(15)01143-0

Amrynudin, A., \& Katharina, R. (2020). Birokrasi Dan Kebijakan Percepatan Penanganan Covid-19. Info Singkat, 12(9), 25-30.

Ashari, E. T. (2019). WA 1-17.

Basrowi, S. (2008). Memahami penelitian kualitatif. Jakarta: Rineka Cipta, 12(1), 128-215.

Brown, R., \& Brignall, S. (2007). Reflections on the use of a dual-methodology research design to evaluate accounting and management practice in UK university central administrative services. Management Accounting Research, 18(1), 32-48. https://doi.org/10.1016/j.mar.2006.07.001

Casu, B., \& Thanassoulis, E. (2006). Evaluating cost efficiency in central administrative services in UK universities. Omega, 34(5), 417-426. https://doi.org/10.1016/j.omega.2004.07.020

Dwiyanto, A. (2013). Mengembalikan kepercayaan publik melalui reformasi birokrasi. Gramedia Pustaka Utama.

Gomes, A. P. M., da Silva, E. G., Gonçalves, S. H. F., Huhtala, M. F. R. L., Martinho, F. C., de Paiva Gonçalves, S. E., \& Torres, C. R. G. (2015). Relationship between patient's education level and knowledge on oral health preventive measures. International Dental \& Medical Journal of Advanced Research, 1(1), 1-7.

Grbich, C. (2012). Qualitative data analysis: An introduction. Sage.

Gumilang, G. S. (2016). Metode penelitian kualitatif dalam bidang bimbingan dan konseling. Jurnal Fokus Konseling, 2(2).

Hadi, S. (1967). Metodologi research.

Hasibuan, M. S., \& Hasibuan, H. M. S. (2016). Manajemen sumber daya manusia. Bumi Aksara.

Herizal, H., Mukhrijal, M., \& Wance, M. (2020). Pendekatan akuntabilitas pelayanan publik dalam mengikuti perubahan paradigma baru administrasi publik. Journal of Governance and Social Policy, 1(1).

Holmes, J., \& Marra, M. (2002). Having a laugh at work: How humour contributes to workplace culture. Journal of pragmatics, 34(12), 1683-1710. https://doi.org/10.1016/S0378-2166(02)00032-2

Hugest, O. E. (1994). Public Management and Administration an Introduction. Martin's Press., New York.

Ibrahim, A. H., Husen, T., Hariyatmoko, K., Djae, R. M., \& Wance, M. (2021). Implementation of Standard Operational Procedures (SOP) Information Dissemination of BMKG Tsunami Early Warning at the Geophysical Statium of Ternate. Annals of the Romanian Society for Cell Biology, 2317-2327.

Kawiana, I. G. P., Dewi, L. K. C., Martini, L. K. B., \& Suardana, I. B. R. (2018). The influence of organizational culture,employee satisfaction, personality, and organizational commitment towards employee performance. International ResearchJournal of Management, IT and Social Sciences, 5(3), 35-45. https://sloap.org/journals/index.php/irjmis/article/view/166

Kim, S. W., \& Su, K. P. (2020). Using psychoneuroimmunity against COVID-19. Brain, behavior, and immunity, 87, 4-5. https://doi.org/10.1016/j.bbi.2020.03.025

Lewin, K. (1951). Field theory in social science: selected theoretical papers (Edited by Dorwin Cartwright.).

Luthans, F. (2006). Perilaku organisasi.

Mandala, I. G. N. A. K., \& Astika, I. B. P. (2019). Effect of work environment, quality of system and work culture on satisfaction of accounting information system user. International Research Journal of Management, IT and Social Sciences, 6(4), 37-43. https://doi.org/10.21744/irjmis.v6n4.633

Mangkunegara, A. A. P. (2011). Manajemen sumber daya manusia perusahaan.

Matdoan, M. Y., Wance, M., \& Balami, A. M. (2021, September). Ridge regression modeling in overcoming multicollinearity problems in multiple linear regression models (case study: Life expectancy in Maluku Province). In AIP Conference Proceedings (Vol. 2360, No. 1, p. 020014). AIP Publishing LLC.

Nagendra, H., Munroe, D. K., \& Southworth, J. (2004). From pattern to process: landscape fragmentation and the analysis of land use/land cover change. https://doi.org/10.1016/j.agee.2003.09.003

Nazir, M. (1988). MetodePenelitian. Jakarta: Ghalia Indonesia.

Ndraha, T. (1999). Pengantar teori pengembangan sumber daya manusia.

Notoatmodjo, S. (1992). Pengembangan sumber daya manusia. PT. Rineka Cipta.

Osborne, D., \& Gaebler, T. (1996). Rein-venting Government (Mewirausahakan Birokrasi). Jakarta: PPM.

Parent, M., Vandebeek, C. A., \& Gemino, A. C. (2005). Building citizen trust through e-government. Government Information Quarterly, 22(4), 720-736. https://doi.org/10.1016/j.giq.2005.10.001

Chaniago, W. F. (2021). Work culture of the government of Teluk Ambon district in providing administrative services to the community in the era of COVID-19. International Research Journal of Management, IT and Social Sciences, 8(6), 661-668. https://doi.org/10.21744/irjmis.v8n6.1959 
Phillippi, J., \& Lauderdale, J. (2018). A guide to field notes for qualitative research: Context and conversation. Qualitative health research, 28(3), 381-388.

Porter, W. W., Graham, C. R., Bodily, R. G., \& Sandberg, D. S. (2016). A qualitative analysis of institutional drivers and barriers to blended learning adoption in higher education. The internet and Higher education, 28, 17-27.

Purwanto, E. A. (2019). Kebijakan Publik yang Agile dan Inovatif dalam Memenangkan Persaingan di Era VUCA (Volatile, Uncertain, Complex and Ambiguous). Pidato Pengukuhan Guru Besar Ilmu Kebijakan Publik Fakultas Ilmu Sosial dan Ilmu Politik Universitas Gadjah Mada.

Sedarmayanti, (1996). Restrukturisasi dan Pemberdayaan Organisasi untuk Menghadapi Dinamika Perubahan Lingkungan. CV. Mandar Maju., Bandung.

Suparman, M. A. (2005). Desain Instruksional; M Atwi Suparman.

Suryabrata, S. (2011). Psikologi pendidikan.

Sutrisno, H. A. R. I. (2009). A comparison on biodiversity between private conservation and wildlife reserve forests in Riau by using macro-moths as an indicator. Biodiversitas Journal of Biological Diversity, 10(1).

Tatang, M. A. (1995). Menyusun Rencana Penelitian. Jakarta: PT Raja Grafindo Persada.

Tetro, J. A. (2020). Is COVID-19 receiving ADE from other coronaviruses?. Microbes and infection, 22(2), 72-73. https://doi.org/10.1016/j.micinf.2020.02.006

Thoha, M. (2010). Ilmu Administrasi Publik Kontemporer, Jakarta. Kencana Prenada Media Group.

Tuanaya, W., Tuhumury, J. J., \& Wance, M. (2020). Management Model And Village Fund Allocation During Pandemic Covid-19 In Waiheru Village Ambon Cityindonesia. PalArch's Journal of Archaeology of Egypt/Egyptology, 17(7), 13357-13369.

Verburg, P. H., De Koning, G. H. J., Kok, K., Veldkamp, A., \& Bouma, J. (1999). A spatial explicit allocation procedure for modelling the pattern of land use change based upon actual land use. Ecological modelling, 116(1), 45-61. https://doi.org/10.1016/S0304-3800(98)00156-2

Yildiz, M. (2007). E-government research: Reviewing the literature, limitations, and ways forward. Government information quarterly, 24(3), 646-665. https://doi.org/10.1016/j.giq.2007.01.002 